\title{
Indonesian Journal of Human Nutrition
}

P-ISSN 2442-6636

E-ISSN 2355-3987

www.ijhn.ub.ac.id

Artikel Hasil Penelitian

\section{Pengaruh Waktu dan Suhu Penyimpanan Terhadap Kadar Asam Amino Taurin pada ASI}

\section{(Effect of Storage Time and Temperature on Amino Acid Taurine Levels of Breastmilk)}

\author{
Amalia Ruhana ${ }^{1} *$, Novenda Nur Istiqomah ${ }^{1}$, Bambang Prijadi $^{1}$ \\ ${ }^{1}$ Jurusan Gizi Fakultas Kedokteran Universitas Brawijaya \\ *alamat korespondensi : amaliaruhana@gmail.com
}

Diterima: / Direview: / Dimuat: Januari 2015 / Januari 2015 / Desember 2016

\begin{abstract}
Abstrak
Taurin merupakan sejenis asam amino terbanyak kedua dalam ASI yang berfungsi sebagai neuro-transmitter dan berperan penting untuk proses maturasi sel otak. Pemerahan dan penyimpanan ASI merupakan alternatif cara yang dilakukan oleh ibu yang bekerja untuk tetap bisa memberikan ASI kepada bayinya. Selama penyimpanan ASI terjadi peningkatan proteolisis atau pemecahan protein sehingga diduga terjadi perubahan pada kadar asam amino taurin. Namun, belum terdapat penelitian yang meneliti asam amino secara spesifik terutama asam amino taurin. Tujuan dari penelitian ini adalah untuk mengetahui pengaruh waktu dan suhu penyimpanan ASI terhadap kadar taurin. Penelitian ini menggunakan metode eksperimental dengan memberikan dua faktor perlakuan. Faktor perlakuan pertama yaitu perlakuan penyimpanan pada suhu ruangan, suhu dingin atau refrigerator, dan suhu freezer. Sedangkan faktor perlakuan kedua yaitu perlakuan penyimpanan selama 0 jam, 24 jam, 2 minggu, dan 4 minggu. Pengukuran kadar taurin dilakukan dengan menggunakan HPLC. Dan hasil yang didapatkan adalah suhu penyimpanan berpengaruh secara sigifikan terhadap kadar taurin dengan $\mathrm{p}=0,000$ dan lama waktu penyimpanan berpengaruh secara signifikan terhadap kadar taurin dengan $\mathrm{p}=0,000$. Kesimpulan dari penelitian ini adalah semakin lama waktu penyimpanan maka semakin menurun kadar taurin pada ASI dan semakin tinggi suhu penyimpanan maka semakin menurun kadar taurin pada ASI.
\end{abstract}

Kata Kunci : ASI, Taurin, Penyimpanan, Suhu dan Waktu

\begin{abstract}
Taurine is of the second highest concentration among amino acids in breastmilk which functions as a neuro-transmitter and plays an important role for the maturation of brain cells. Milk expressing and breastmilk storing are alternative ways enabling working mothers to give breastmilk to their babies. During storage of breastmilk, proteolysis or protein breakdown increases, so supposedly a change in the amino acid taurine levels occurs. However, no research
\end{abstract}


has been conducted specifically to examine amino acids, especially amino acid taurine. The purpose of this study is to find out the effect of breastmilk storage duration and temperature on taurin. This study used an experimental method with two-factor treatment. The first treatment factor was the storage treatment at room temperature, cold temperature or refrigerator, and freezer temperature, while the second treatment factor was the duration treatment at 0 hour, 24 hours, 2 weeks, and 4 weeks. Taurine concentration measurement was performed using HPLC. The result obtained is that storage temperature significantly influences the level of taurine with $\mathrm{p}=0.000$, and storage duration significantly affects the level of taurine with $\mathrm{p}=0.000$. This study concludes that the longer duration of storage, the lower taurine levels in breast milk; and the higher the temperature of storage, the lower taurine levels in breast milk.

Keywords: breastmilk, taurine, storage, temperature, duration

\section{PENDAHULUAN}

Air Susu Ibu (ASI) memiliki kandungan zat gizi yang lengkap dan sempurna serta mengandungi zat anti infeksi [1]. Taurin adalah sejenis asam amino terbanyak kedua dalam ASI [2]. Kandungan taurin pada ASI diketahui lebih tinggi dibandingkan pada susu sapi [3]. Taurin berfungsi sebagai neurotransmitter dan berperan penting untuk proses maturasi sel otak [4]. Kemampuan perkembangan mental dan motorik seorang anak berkorelasi dengan konsentrasi taurin plasma pada masa bayi [5]. Penelitian pada hewan coba menunjukkan bahwa kekurangan taurin akan berakibat terjadinya gangguan pada retina mata [6]. Hal ini disebabkan oleh taurin pada tahap perkembangan juga berperan penting dalam promosi diferensiasi fotoreseptor dan mungkin terlibat dalam pematangan retina sebagai organ [7]. Pemberian ASI dapat menurunkan risiko defisiensi taurin [8].

Menurut hasil survei Riskesdas tahun 2010, persentase ibu di Indonesia yang memberikan ASI eksklusif pada bayi umur 0 bulan adalah 39,8\%. Persentase tersebut menurun seiring dengan bertambahnya usia bayi, yaitu 30,7\% pada bayi usia 2 bulan dan hanya $15,3 \%$ saja pada bayi usia 5 bulan [9]. Penyebab utama ibu tidak memberikan ASI eksklusif kepada bayinya terutama di daerah perkotaan adalah karena ibu aktif bekerja [10]. Pemerintah di Indonesia hanya menetapkan cuti melahirkan sesuai UU Tenaga Kerja Nomor 13 Tahun 2003 yaitu selama 3 bulan saja. Cuti menyusui hanya dilakukan oleh sedikit institusi bagi pekerjanya. Dengan masa cuti yang sempit, kesempatan ibu memberikan ASI eksklusif pun terbatas [11].

Sekarang semakin banyak ibu yang sadar akan pentingnya pemberian ASI sehingga terdapat beberapa alternatif untuk ibu yang bekerja agar tetap bisa memberikan ASI kepada bayinya. Memerah ASI adalah alternatif yang banyak dilakukan saat ini. Hasil ASI perah yang dihasilkan akan disimpan agar dapat diminum bayi setiap saat. Terdapat beberapa pedoman dalam penyimpanan ASI, seperti pedoman dari CDC (Centers for Disease Control and Prevention) tahun 2008 yang menyatakan bahwa ASI dapat disimpan di suhu ruang $\left(77^{\circ} \mathrm{F}\right.$ atau $\left.25^{\circ} \mathrm{C}\right)$ selama 6-8 jam, di refrigerator $\left(39^{\circ} \mathrm{F}\right.$ atau $4^{0} \mathrm{C}$ ) selama 5 hari, dan di freezer yang terpisah dengan refrigerator $\left(0^{0} \mathrm{~F}\right.$ atau $\left.-18^{0} \mathrm{C}\right)$ selama $3-8$ bulan [12].

Penelitian yang dilakukan oleh Fogleman (2008) tentang efek waktu dan suhu penyimpanan pada kandungan gizi ASI menunjukkan bahwa terdapat penurunan yang signifikan pada total protein sampel susu yang disimpan pada suhu $24^{0} \mathrm{C}$ setelah 24 jam. Selain itu, penelitian menunjukkan bahwa peningkatan proteolisis secara signifikan pada sampel ASI yang disimpan di suhu $4^{0} \mathrm{C}$ selama seminggu dan $24^{\circ} \mathrm{C}$ selama 3 minggu. Peningkatan proteolisis atau pemecahan protein menjadi peptida dan asam amino ini yang berdampak pada peningkatan jumlah asam amino bebas [13]. Namun, pada penelitian tersebut tidak meneliti asam amino secara spesifik terutama asam amino taurin. 
Taurin diketahui mempunyai umur simpan atau self life yang panjang, namun terdapat perbedaan umur simpan pada kondisi penyimpanan tertentu [14]. Tujuan dari penelitian ini adalah untuk mengetahui pengaruh waktu dan suhu penyimpanan terhadap kadar asam amino taurin pada ASI.

\section{METODE PENELITIAN \\ Rancangan/Desain Penelitian}

Penelitian ini menggunakan metode true experimental dengan Rancangan Acak Lengkap Faktorial menggunakan kontrol awal dan memberikan dua faktor perlakuan. Faktor perlakuan pertama yaitu perlakuan penyimpanan pada suhu ruangan, suhu dingin atau refrigerator, dan suhu freezer. Faktor perlakuan kedua yaitu perlakuan penyimpanan selama 0 jam, 24 jam, 2 minggu, dan 4 minggu. Kemudian, masing-masing perlakuan di atas diukur kadar asam amino taurin pada sampel ASI yang digunakan dalam penelitian.

\section{Sampel Penelitian}

Besar sampel dihitung secara manual berdasarkan banyak perlakuan yang diberikan dan pengulangan yang diinginkan. Dalam penelitian ini, peneliti memberikan 12 perlakuan dengan 2 kali pengulangan, sehingga peneliti membutuhkan jumlah sampel ASI sebanyak 24 yang akan diambil dari 6 responden ibu menyusui (25-40 tahun) dalam masa laktasi 1-3 bulan yang berdomisili di Kelurahan Cilendek Kota Bogor. ASI yang diambil dari setiap responden sebesar $100 \mathrm{ml}$ ASI. Sampel ASI yang diambil dari setiap responden akan digunakan untuk 1 jenis perlakuan suhu penyimpanan dengan 4 jenis perlakuan waktu penyimpanan.

\section{Pengembangan Instrument dan Teknik Pengumpulan Data}

Responden direkrut dari informasi di Posyandu Kelurahan Cilendek Barat. Peneliti menanyakan langsung kepada calon responden mengenai kesediaannya menjadi responden. Peneliti mengatur dan mencatat waktu dan tempat pertemuan untuk mengumpulkan ASI dari responden. Selain itu peneliti memberikan wadah atau plastik steril untuk menampung ASI kepada para responden. Pada hari pengumpulan ASI, setiap responden memompa seluruh isi satu atau kedua payudara seperti yang biasa dilakukan. Para responden menempatkan ASI ke dalam wadah steril yang telah diberikan, dan menyimpan ASI kedalam lemari es untuk penyimpanan sementara sampai pengambilan oleh peneliti.

Ketika susu dikumpulkan dari tiap responden, wadah atau plastik steril ASI yang sudah berisi ASI ditempatkan di kotak pendingin es untuk transportasi ke laboratorium. Saat di laboratorium, sampel ASI dipindahkan ke botol yang sudah disiapkan. Setiap sampel ASI dari responden akan dibagi menjadi 4, Kemudian botol-botol tersebut diberi label dengan informasi nomor, waktu, dan suhu penyimpanan. Seluruh sampel yang sudah siap disimpan di suhu ruang, suhu dingin, dan suhu freezer. Setiap sampel akan dianalisis kadar taurin menggunakan HPLC dengan selang waktu 0 jam, 24 jam, 2 minggu, dan 4 minggu.

\section{Teknik Analisis Data}

Analisis statistik menggunakan two way ANOVA untuk mengetahui apakah suhu dan waktu penyimpanan dapat memengaruhi kadar asam amino taurin pada ASI serta Pearson untuk mengetahui hubungan antara waktu dan suhu penyimpanan terhadap kadar asam amino taurin pada ASI. Dalam penelitian ini derajat kepercayaan yang digunakan adalah $95 \%$ dengan $\alpha=0,05$ menggunakan instrumen SPSS 16 for Windows.

\section{HASIL PENELITIAN}

\section{Kadar Taurin pada ASI Sebelum Disimpan}

Pada penelitian ini, dilakukan pengukuran kadar taurin pada ASI yang baru dikumpulkan dari responden dan tidak mengalami perlakuan penyimpanan. Dari penelitian yang dilakukan, rata-rata kadar taurin ASI pada jam ke-0 atau sebelum disimpan adalah 75,98 $\mathrm{mg} / \mathrm{kg}$. 


\section{Kadar Taurin ASI Selama Penyimpanan}

Berdasarkan hasil pengukuran kadar taurin pada ASI yang disimpan pada suhu ruang menunjukkan bahwa kadar taurin mengalami penurunan. Rata-rata kadar taurin pada penyimpanan suhu ruang pada 24 jam pertama adalah $3,95 \mathrm{mg} / \mathrm{kg}$, sedangkan kadar taurin awal atau pada jam ke-0 adalah 82,94 $\mathrm{mg} / \mathrm{kg}$. Kadar taurin terus mengalami penurunan pada suhu ruang selama penyimpanan 2 minggu yaitu menjadi $1,89 \mathrm{mg} / \mathrm{kg}$ hingga penyimpanan selama 4 minggu mencapai kadar $1,63 \mathrm{mg} / \mathrm{kg}$. Data kadar taurin ASI pada penyimpanan tersaji dalam Tabel 1 .

Dari Tabel 1 dapat diketahui bahwa terjadi penurunan kadar taurin ASI yang disimpan pada suhu dingin atau refrigerator seiring dengan peningkatan lama waktu penyimpanan. Sampel ASI pada jam ke 0 memiliki kadar taurin tertinggi yaitu sebesar $74,50 \mathrm{mg} / \mathrm{kg}$ yang kemudian menurun pada 24 jam pertama hingga penyimpanan selama 4 minggu. Kadar taurin pada 24 jam pertama adalah sebesar 33,94 mg/kg yang kemudian terus mengalami penurunan pada penyimpanan selama 2 minggu yaitu sebesar 29,68 $\mathrm{mg} / \mathrm{kg}$ hingga pada penyimpanan selama 4 minggu mencapai $25,22 \mathrm{mg} / \mathrm{kg}$.

Pada Tabel 1 juga dapat diketahui bahwa terjadi penurunan kadar taurin ASI yang disimpan pada suhu beku atau freezer seiring dengan peningkatan lama waktu penyimpanan. Sampel ASI pada jam ke-0 memiliki kadar taurin tertinggi yaitu sebesar 70,53 $\mathrm{mg} / \mathrm{kg}$ yang kemudian menurun pada 24 jam pertama hingga penyimpanan selama 4 minggu meskipun penurunan kadar taurin tersebut tidak sebesar yang terjadi pada penyimpanan suhu ruang dan suhu dingin. Kadar taurin pada 24 jam pertama adalah sebesar $62,87 \mathrm{mg} / \mathrm{kg}$ yang kemudian terus mengalami penurunan pada penyimpanan selama 2 minggu yaitu sebesar $61,20 \mathrm{mg} / \mathrm{kg}$ hingga pada penyim-panan selama 4 minggu mencapai $48,19 \mathrm{mg} / \mathrm{kg}$.

\section{Pengaruh Waktu dan Suhu Penyimpanan Terhadap Kadar Asam Amino Taurin pada ASI}

Untuk mengetahui pengaruh waktu dan suhu penyimpanan terhadap kadar taurin pada ASI, uji regresi yang dilakukan adalah uji Two Way ANOVA. Hasil data statistik uji regresi disajikan dalam Tabel 2.

Dari hasil uji, diperoleh nilai $\mathrm{p}<0,000$ sehingga dapat diketahui bahwa terdapat pengaruh yang bermakna antara waktu dan suhu penyimpanan dengan kadar taurin pada ASI.

Untuk mengetahui hubungan waktu dan suhu penyimpanan dengan kadar taurin pada ASI, uji korelasi yang dilakukan adalah uji Pearson. Hasil data statistik uji korelasi disajikan dalam Tabel 3.

Dari hasil uji, diperoleh nilai $\mathrm{p}=0,002$ sehingga dapat diketahui bahwa terdapat hubungan yang bermakna antara variabel waktu penyimpanan dengan kadar taurin. Nilai Korelasi Pearson sebesar -0,601 menunjukkan bahwa arah korelasi negatif dengan kekuatan korelasi ( $r$ ) kuat, sedangkan untuk variabel suhu penyimpanan diperoleh nilai $\mathrm{p}=0,006$ sehingga dapat disimpulkan bahwa terdapat hubungan yang bermakna antara variabel suhu penyimpanan dengan kadar taurin. Nilai korelasi Pearson sebesar -0,55 menunjukkan bahwa arah korelasi negatif dengan kekuatan korelasi ( $r$ ) kuat.

\section{PEMBAHASAN}

\section{Kadar Taurin pada ASI Sebelum Disimpan}

Kandungan taurin pada ASI diketahui jauh lebih tinggi dibandingkan pada susu sapi. Kandungan rata-rata taurin ASI pada 40 orang ibu menyusui di Eropa adalah 301,1 $\mu \mathrm{m} / \mathrm{L}$ [3]. Kandungan rata-rata taurin pada ASI yang diambil dari ibu menyusui di beberapa daerah di Jepang dan Italia adalah 7,00-6,56 $\mathrm{mg} / 100 \mathrm{~cm}^{3}$ dan $301 \mu \mathrm{m} / \mathrm{dm}^{3}$ [2]. 
Tabel 1. Data Kadar Taurin ASI (mg/kg)

\begin{tabular}{ccccccccccc}
\hline \multirow{2}{*}{ Metode } & \multicolumn{3}{c}{ Suhu Ruang } & \multicolumn{3}{c}{ Suhu Dingin } & \multicolumn{2}{c}{ Suhu Freezer/Beku } \\
\cline { 2 - 10 } & A & B & Rata-rata & A & B & $\begin{array}{c}\text { Rata- } \\
\text { rata }\end{array}$ & A & B & $\begin{array}{c}\text { Rata- } \\
\text { rata }\end{array}$ \\
\hline 0 jam & 82,44 & 83,43 & 82,935 & 75,32 & 73,68 & 74,5 & 65,4 & 75,65 & 70,525 \\
24 jam & 4,05 & 3,84 & 3,945 & 32,67 & 35,2 & 33,935 & 51,37 & 74,37 & 62,87 \\
$\mathbf{2}$ minggu & 2 & 1,77 & 1,885 & 28,47 & 30,88 & 29,675 & 47,89 & 74,5 & 61,195 \\
4 minggu & 1,51 & 1,74 & 1,625 & 23,03 & 27,41 & 25,22 & 45,73 & 52,64 & 49,185 \\
\hline
\end{tabular}

Tabel 2. Pengaruh Waktu dan Suhu Penyimpanan Terhadap Kadar Taurin ASI

\begin{tabular}{clc}
\hline $\begin{array}{c}\text { Variabel } \\
\text { Dependen }\end{array}$ & \multicolumn{1}{c}{ Variabel Independen } & Sig. \\
\hline \multirow{3}{*}{ Kadar Taurin } & Waktu Penyimpanan & 0,000 \\
& Suhu Penyimpanan & 0,000 \\
& Waktu dan Suhu Penyimpanan & 0,000 \\
\hline
\end{tabular}

Tabel 3. Hubungan Waktu dan Suhu Penyimpanan Terhadap Kadar Taurin ASI

\begin{tabular}{clcc}
\hline Variabel Dependen & Variabel Independen & $\boldsymbol{P}$ & $\begin{array}{c}\text { Kekuatan } \\
\text { Korelasi } \\
(\boldsymbol{r})\end{array}$ \\
\hline \multirow{2}{*}{ Kadar Taurin } & Waktu Penyimpanan & $p=0,002$ & $-0,601$ \\
& Suhu Penyimpanan & $p=0,006$ & $-0,544$ \\
\hline
\end{tabular}

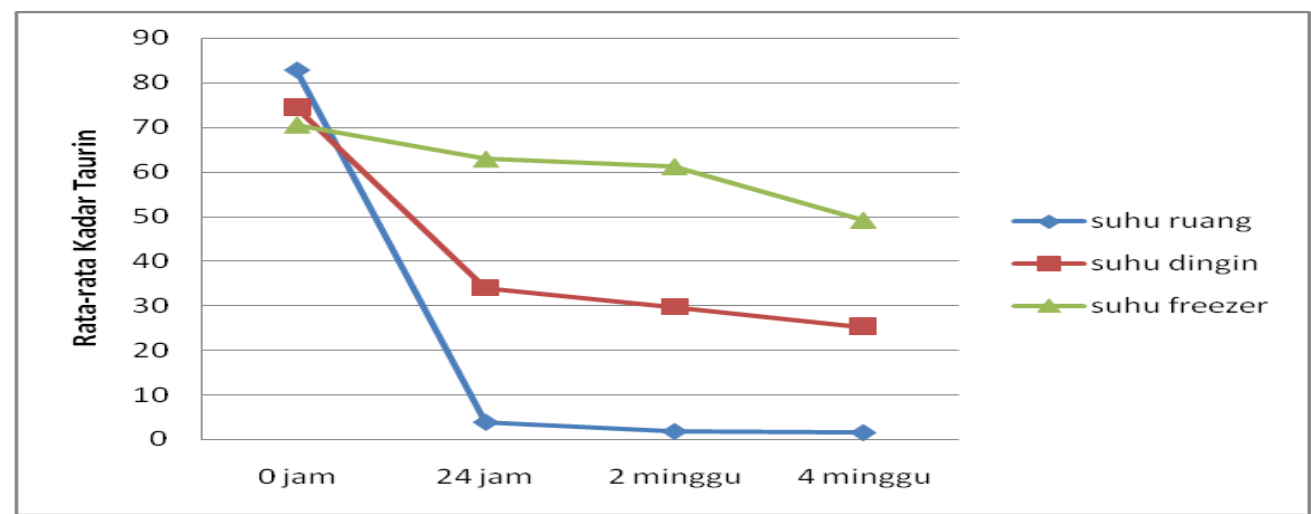

Gambar 1. Rata-rata Kadar Taurin pada Penyimpanan Berdasarkan Waktu dan Suhu

Rata-rata kadar taurin pada kelompok responden perlakuan suhu ruang sebesar $82,94 \mathrm{mg} / \mathrm{kg}$, suhu dingin sebesar 74,50 $\mathrm{mg} / \mathrm{kg}$, dan suhu beku sebesar $70,53 \mathrm{mg} / \mathrm{kg}$. Perbedaan tersebut disebabkan oleh komposisi ASI tidak seragam dan dapat berubah dari waktu ke waktu karena komposisi dipengaruhi stadium laktasi, ras, diet ibu, dan keadaan gizi [15]. Berdasarkan stadium laktasi dibedakan menjadi 3 stadium, yaitu kolostrum, ASI peralihan, dan ASI matur. Cairan kolostrum berwarna kekuningkuningan dan lebih kental karena banyak mengandung protein dan vitamin A yang tinggi selain itu kolostrum juga mengandung zat kekebalan tubuh yang penting untuk 
melindungi bayi dari penyakit infeksi. Vitamin yang larut dalam lemak lebih tinggi daripada ASI masa matur [16].

Diet ibu juga merupakan faktor utama yang memengaruhi konsentrasi banyak molekul zat gizi yang penting dalam ASI. Ada bukti penelitian besar menunjukkan bahwa keberadaan asam lemak esensial (omega 3) dalam ASI tergantung pada asupan makanan ibu [17]. Selain itu, komponen zat gizi ASI diturunkan dari 3 sumber, yaitu beberapa zat gizi ASI berasal dari sintesis laktosit, beberapa asli dari makanan atau diet, dan beberapa berasal dari simpanan dalam tubuh ibu yang berbeda-beda [18].

\section{Pengaruh Waktu dan Suhu Penyimpanan Terhadap Kadar Taurin ASI}

Umur simpan atau masa simpan adalah waktu yang diperlukan oleh produk pangan dalam kondisi penyimpanan tertentu untuk dapat mencapai tingkatan degradasi mutu tertentu. Mutu dari suatu produk pangan termasuk susu ditentukan berdasarkan karakteristik penampakan, rasa, aroma, tekstur, dan nilai gizi [19]. Menurut Academy Breasfeeding Medicine (2010), masa simpan ASI dapat bertahan hingga 6 bulan dengan penyimpanan pada suhu freezer, hingga 72 jam dengan penyimpanan suhu dingin/refrigerator dan 3-4 jam dengan penyimpanan suhu ruang [12].

Hasil penelitian ini membuktikan bahwa waktu penyimpanan memberikan pengaruh yang signifikan terhadap kadar taurin ASI. Dari seluruh sampel ASI yang disimpan baik pada suhu ruang, suhu dingin, maupun suhu beku mengalami penurunan dari waktu penyimpanan 24 jam, 2 minggu, hingga mencapai waktu penyimpanan 4 minggu. Sehingga semakin lama waktu penyimpanan ASI maka kadar taurin pada ASI juga semakin menurun.

Terdapat tiga jenis perlakuan suhu penyimpanan pada penelitian ini, yaitu penyimpanan suhu ruang, suhu dingin/ refrigerator, dan suhu beku/freezer. Penelitian ini mendukung hipotesis bahwa suhu penyimpanan memberikan pengaruh yang signifikan terhadap parameter kadar taurin pada ASI.

Kadar taurin selama penyimpanan pada ketiga jenis suhu penyimpanan mengalami penurunan. Pada penyimpanan selama 24 jam di suhu ruang telah terjadi penurunan kadar taurin sebesar $95,24 \%$. Selama penyimpanan pada suhu ruang kadar taurin mengalami penurunan hingga mencapai 98,04\%, sedangkan pada suhu dingin kadar taurin mengalami penurunan hingga mencapai $66.14 \%$ dan selama penyimpanan pada suhu beku terjadi kehilangan taurin pada ASI hanya sebesar $30,5 \%$. Penelitian ini membuktikan bahwa semakin tinggi suhu penyimpanan ASI maka kadar taurin pada ASI juga semakin menurun. Sehingga penyimpanan pada suhu rendah yang dapat mempertahan kadar taurin pada ASI.

Hal tersebut sesuai dengan prinsip penyimpanan suhu rendah adalah memperlambat kecepatan reaksi metabolisme dan menghambat pertumbuhan mikroorganisme penyebab kebusukan dan kerusakan [20]. Penyimpanan pada suhu rendah dapat menghambat aktivitas enzim dan reaksi-reaksi kimia serta menghambat atau menghentikan pertumbuhan mikroba. Tujuan lain penyimpanan suhu rendah $\left(10^{\circ} \mathrm{C}\right)$ adalah untuk mencegah kerusakan pada bahan pangan seperti terjadinya pembusukan. Perlakuan peyimpanan suhu dingin atau rendah juga dapat memperlambat kecepatan reaksi-reaksi metabolisme, seperti pada umumnya akan terjadi pengurangan kecepatan reaksi menjadi setengahnya setiap penurunan suhu $8^{\circ} \mathrm{C}$. Oleh karena itu, dengan adanya proses respirasi yang menurun dan terhambatnya pertumbuhan mikroba penyebab kebusukan dan kerusakan pada penyimpanan suhu rendah dapat mengakibatkan perpanjangan masa hidup dari jaringan-jaringan di dalam bahan pangan tersebut [21].

Taurin diketahui mempunyai umur simpan atau self life yang panjang yaitu 6 bulan dengan penyimpanan pada suhu $40^{\circ} \mathrm{C}$. Taurin yang dimasukkan ke dalam campuran mineral dan disimpan pada suhu $25^{\circ} \mathrm{C}$ mempunyai masa simpan hingga 4 bulan. Taurin stabil dalam larutan $1 \%$ dan $2 \%$ (air 
keran) apabila disimpan pada suhu kamar di tempat gelap selama satu minggu [12] . Adanya penurunan kadar taurin selama proses penyimpanan pada penelitian ini disebabkan oleh adanya peng-gunaan taurin sebagai sumber nitrogen untuk pertumbuhan bakteri pada sampel ASI tersebut. Sesuai dengan penelitian yang dilakukan oleh Cheng-Ye dan Zhi-Yu (1998) menunjukkan bahwa selama proses penyimpanan tiram dengan kandungan taurin yang tinggi, sama dengan asam amino lainnya taurin juga digunakan sebagai sumber nitrogen untuk pertumbuhan bakteri [22]. Susu merupakan media yang baik untuk pertumbuhan mikroba sehingga apabila tidak ditangani dengan tepat dan cepat maka akan mengakibatkan kerusakan bahkan pembusukan. Oleh karena itu proses pendinginan adalah salah satu cara untuk menekan pertumbuhan mikroba khususnya bakteri [23].

Hal tersebut juga sejalan dengan hasil penelitian yang dilakukan oleh Fogleman (2008), yang mengemukakan bahwa secara statistik adanya pertumbuhan tidak konstan bakteri yang signifikan pada ASI yang disimpan pada suhu $4^{0} \mathrm{C}(\mathrm{p}<0,01)$ dan $24^{\circ} \mathrm{C}$ $(\mathrm{p}<0,0001)$ selama penyimpanan 3 minggu. Sampel yang disimpan pada suhu $24^{0} \mathrm{C}$ selama 48 jam terjadi peningkatan pertumbuhan bakteri secara signifikan $(p<0,01)$ [13]. Sesuai dengan hasil penelitian ini bahwa terjadi penurunan kadar taurin yang signifikan pada penyimpanan ASI di suhu ruang dan suhu refrigerator.

Meskipun taurin termasuk ke dalam kelompok asam amino, namun taurin tidak dimasukkan dalam kelompok protein karena taurin adalah asam amino non esensial yang mengandung sulfur dan mengandung gugus amino, tetapi tidak memiliki gugus karboksil yang diperlukan untuk membentuk ikatan peptida. Itu sebabnya, molekul tersebut tidak berfungsi sebagai pembangun struktur protein. Taurin tidak mempunyai kodon genetik dan tidak tergabung dalam protein dan enzim [24]. Maka dari itu, hasil penelitian ini sedikit berbeda dengan hasil Fogleman (2008) yang menemukan bahwa adanya peningkatan asam amino bebas pada ASI yang diberikan perlakuan penyimpanan pada suhu $4^{0} \mathrm{C}$ dan suhu $24^{\circ} \mathrm{C}$ selama 3 minggu. Peningkatan asam amino bebas pada ASI dikarenakan adanya pemecahan protein menjadi peptida dan asam amino yang kemudian akan digunakan kembali untuk membentuk protein. Maka dari itu, meskipun asam amino bebas meningkat pada sampel ASI yang disimpan pada suhu $4^{0} \mathrm{C}$ (sampai 3 minggu), namun total protein ditemukan tetap stabil.

Dari hasil penelitian ini menunjukkan bahwa suhu penyimpanan dan lama waktu penyimpanan berpengaruh terhadap kadar taurin dalam ASI. Meskipun beberapa zat gizi dan komponen penting akan berubah selama penyimpanan, namun setidaknya terdapat pendekatan yang baik dalam penanganan penyimpanan terkait suhu dan waktu agar ASI tersebut tetap aman untuk dikonsumsi bayi masih mengandung nilai gizi yang optimal terutama taurin yang berperan penting dalam maturasi sel otak. Berdasarkan hasil penelitian ini dapat direkomendasikan bahwa untuk penyimpanan ASI sebaiknya dilakukan pada suhu beku atau freezer karena perubahan kadar taurin yang terjadi selama penyimpanan pada suhu beku tidak sebesar perubahan yang terjadi pada penyimpanan suhu ruang dan suhu dingin. Penyimpanan ASI pada suhu ruang sebaiknya dilakukan kurang dari 24 jam karena pada penyimpanan suhu ruang selama 24 jam terjadi penurunan kadar taurin.

\section{KESIMPULAN}

Rata-rata kadar taurin pada ASI sebelum disimpan atau pada jam ke-0 adalah $75,98 \mathrm{mg} / \mathrm{kg}$. Rata-rata kadar taurin pada ASI yang disimpan selama 24 jam, 2 minggu, dan 4 minggu mengalami penurunan yang signifikan. Semakin lama waktu penyimpanan maka semakin menurun kadar taurin pada ASI. Rata-rata kadar taurin pada ASI mengalami penurunan yang signifikan selama penyimpanan pada suhu ruang, suhu dingin, dan suhu beku. Semakin tinggi suhu penyimpanan maka semakin menurun kadar taurin pada ASI. Penyimpanan ASI paling baik dilakukan pada suhu beku atau freezer dan untuk 
penyimpanan ASI pada suhu ruang sebaiknya dilakukan kurang dari 24 jam.

\section{DAFTAR RUJUKAN}

1. Perinasia. Manajemen Laktasi. Menuju Persalinan Aman dan Bayi Lahir Sehat, 2nd ed. Jakarta; 2004. 15-35.

2. Csap'o J, Salamon SZ. Composition of the Mother's Milk I. Protein contents, amino acid Composition, Biological Value. University of Kaposv'ar, Faculty of Animal Science. 2009; 2 (2): 174-195.

3. Agostoni C, Carrutu B, Boniglia C, Riva E, Sanzini E. Free Amino Acid Content in Standard Infant Formula Comparison with Human Milk. Journal of The American College of Nutrition. 2000; 19 (4): 434438.

4. Hohmann C. Nutrition, Brain, and Environment: How to have Smarter Babies? Journal Indian Pediatrics. 2003; 40: 213-220.

5. Heird WC. Taurine in Neonatal Nutrition - Revisited. Arch Dis Child Fetal Neonatal Ed. 2004; 89: F473-F474.

6. Depkes RI. Buku Panduan Manajemen Laktasi. Jakarta: Direktorat Gizi Masyarakat-Depkes RI; 2001.

7. L'Amoreaux W. The Role of Taurine in the Retina. Taurine in Health and Disease. 2012: 215-254.

8. Lourenço R, Camilo ME. Taurine: A Conditionally Essential Amino Acid in Humans? An Overview in Health and Disease. Nutrition Hospital Journal. 2002; 17 (6): 262-270.

9. Riskesdas. Riset Kesehatan Dasar. Jakarta: Badan Penelitian dan Pengembangan Kesehatan Kementerian Kesehatan RI; 2010. 60-173.

10. Sibuea D. Problema Ibu Menyusui [skripsi]. Medan: Universitas Sumatera Utara; 2003. Bagian Obstetri-Ginekologi Fakultas Kedokteran Universitas Sumatera Utara.

11. Sari TP. Pemerintah Dituntut Berikan Cuti Menyusui pada Ibu Pekerja [koran di internet). 2009 (diunduh pada tanggal 22 November 2012). Available from: http://www.metrotvnews.com .
12. Bunik M, Chantry CJ, Howard CR, Lawrence RA, Marinelli KA, Noble L, et al. ABM Clinical Protocol \#8: Human Milk Storage Information for Home Use for Full-Term Infants (Original Protocol March 2004; Revision \#1 March 2010) . Journal Breastfeeding Medicine. 2010; 5 (3): 127-130.

13. Fogleman AD. 2008. Effect of Storage Time and temperature on Components in Human Breast Milk [thesis]. Raleigh: North Carolina State University; 2008.

14. EFSA. Scientific Opinion on the Safety and Efficacy of Taurine as a Feed Additive for All Animal Species. European Food Savety Authoruty Journal. 2012; 10 (6): 2736-2740.

15. Suraatmaja S. ASI Petunjuk untuk Tenaga Kesehatan: Aspek Gizi Air Susu Ibu. Jakarta: EGC; 1997. 12-16.

16. Soetjiningsih. Tumbuh Kembang Anak dan Remaja. Jakarta: Sagung Seto; 2002. 24-40.

17. Roumeliotou E. How Maternal Diet and Lifestyle Affects the Nutritional Value of Breast Milk [Dokumen di Internet]. 2013 (diunduh 5 Juni 2014). Available from: http://www.greenmed.com .

18. Ballard O, Morrow AL. Human Milk Compotition: Nutrients and Bioactive Factors. Journal of Peditric Clinical N Am. 2013; 60: 49-74.

19. Herawati H. Penentuan Umur Simpan Pada Produk Pangan. Jurnal Litbang Pertanian: 2008; 27 (4). 124-130.

20. Dwi D. ASI: Tips Memerah, Menyimpan, dan Memberikan pada Bayi. 2011 (diunduh 25 November 201). Available from: http://desiemeilana.wordpress.com .

21. Purnawijayanti H. Sanitasi Higiene dan Keselamatan Kerja dalam Pengolahan Makanan . Jogjakarta: Kanisius; 2001. 6684.

22. Cheng-Ye, Zhi-Yu. Regular Changes of Free Amino Acid and Taurine During Oyster Freshness Preservation [Thesis]. Xiamen: Fujian Fisheries Research Institute; 1998. 
23. Sunarlim R, Setiyanto H. 2005. Balai Besar Penelitian dan Pengembangan Pascapanen Pertanian, Bogor.
24. Ripps, Shen. Review: Taurine: A "very essential" Amino Acid. Journal Molecular Vision. 2012; 18: 2673-2686. 